\title{
PENGEMBANGAN PERANGKAT PEMBELAJARAN IPA TERPADU TIPE CONNECTED POKOK BAHASAN PENCEMARAN AIRDENGAN SUMBER BELAJAR LINGKUNGAN SEKITAR PADA SISWA SMP
}

\author{
Hasyim As'ari ${ }^{1)}$ \\ Soeparman Kardi ${ }^{2}$ \\ Tjandrakiran ${ }^{2)}$ \\ 1) Mahasiswa Pendidikan Sains Pascasarjana Unesa \\ 2) Dosen Prodi Pendidikan Sains Program Pascasarjana Unesa \\ e-mail:hasyim_aja@hotmail.com
}

\begin{abstract}
Abstrak: Telah dilakukan suatu penelitian pengembangan perangkat pembelajaran IPA terpadu tipe connected dengan model Dick and Carey pada pokok bahasan pencemaran air dan bertujuan untuk meningkatkan hasil belajar siswa SMP. Subyek penelitian perangakat pembelajaran yang diujicobakan pada 32 siswa SMP dengan rancangan one group pretest-posttest,sedangkan analisis data secara deskriptif kuantitatif. Hasil validasi perangkat pembelajaran valid, keterlaksanaan pembelajaran baik. Tes hasil belajar siswa dianalisis dengan $\mathrm{N}$-Gain mengalami peningkatan, kemampuan psikomotor siswa baik, dan perangkat pembelajaran dapat mengembangkan sikap siswa. Simpulan penelitian ini, bahwa perangkat pembelajaran IPA terpadu tipe connected dengan sumber belajar lingkungan sekitar pada siswa SMP layak dan dapat meningkatkan hasil belajar siswa.
\end{abstract}

Kata Kunci: IPA terpadu tipe connected, hasil belajar siswa.

\begin{abstract}
Research development of Integrated Science teaching materials connected type with Dick and Carey model on subject matter water pollution and which aims to improve the learning outcomes of students. The research subject of teaching materials which tested on 32 student of junior high school with design one-group pretest-posttest, and analyzed using descriptive quantitative. The results are validation of teaching materials is valid, learning performance is good. Tests of students learning outcomes were analyzed with $N$-Gain Increased. Psychomotor skills of students is good), and the teaching materials can develop to students attitudes. The conclusion of this research, that the integrated science teaching materials connected type with environment source learning students in junior high school is feasible and can improve the learning outcomes of students.
\end{abstract}

Keywords: Integrated Science Connected Type, improve the learning outcomes of students.

\section{PENDAHULUAN}

Kurikulum Tingkat Satuan Pendidikan (KTSP) untuk tingkat SMP memiliki esensial sebagai berikut; (1) mata pelajaran tertentu mendukung kompetensi tertentu, (2) mata pelajaran dirancang berdiri sendiri dan memiliki kompetensi dasar sendiri, (3) Bahasa Indonesia sebagai pengetahuan, (4) tiap mata pelajaran diajarkan dengan pendekatan yang berbeda, dan (5) Teknologi Informatika dan Komunikasi (TIK) adalah mata pelajaran sendiri (Mulyasa, 2013). Berdasarkan esensial tersebut, maka proses pembelajaan dalam kurikulum KTSP ada kecenderungan selama ini guru mengemas pengalaman belajar siswa terkotak-kotak dengan tegas antara satu bidang studi dengan bidang studi yang lain. Pembelajaran yang memisahkan penyajian mata pelajaran secara tegas akan membuat kesulitan belajar bagi siswa, karena pemisahan seperti itu akan memberikan pengalaman belajar yang artifisial. Pengalaman belajar yang artifisial, akan menjauhkan dunia pendidikan dari tujuan riilnya, karena hanya menekankan pada pencapaian tuntutan kurikulum dan penyampaian tekstual semata daripada mengembangkan kemampuan belajar dan membangun karakter siswa (Poerwati \& Amri, 2013).

Pembelajaran Ilmu Pengetahuan Alam (IPA) yang dilakukan di Sekolah Menengah Pertama (SMP) seharusnya diberikan secara terpadu. Melalui pembelajaran IPA terpadu, siswa dapat memperoleh pengalaman langsung, sehingga dapat menambah kekuatan untuk menerima, menyimpan, dan menerapkan konsep yang telah dipelajarinya. Siswa dengan demikian, terlatih untuk dapat menemukan sendiri berbagai konsep yang dipelajari secara menyeluruh (holistik), bermakna, otentik dan aktif (Trianto, 2013). Cara pengemasan pengalaman belajar yang dirancang guru sangat berpengaruh terhadap kebermaknaan pengalaman bagi para siswa. Pengalaman belajar yang lebih menunjukkan kaitan unsur-unsur konseptual akan menjadikan proses belajar lebih efektif. Kaitan konseptual yang dipelajari dengan sisi bidang kajian IPA yang relevan akan membentuk skema kognitif, sehingga anak memperoleh 
keutuhan dan kebulatan pengetahuan. Keutuhan belajar IPA, serta kebulatan pandangan tetang kehidupan, dunia nyata dan fenomena alam hanya dapat direfleksikan melalui pembelajaran IPA terpadu (Puskur, 2007).

Hasil ulangan tengah semester mata pelajaran IPA semester 1 Tahun Ajaran 2013/2014 kelas VII SMP Negeri 1 Sedati Sidoarjo menunjukkan bahwa ketuntasan hasil belajar siswa kurang dari 50\% dengan Kreteria Ketuntasan Minimal (KKM) 70. Hasil observasi selama kegiatan belajar mengajar ternyata: (1) dalam pembelajaran IPA yang dilakukan guru sudah mendukung metode ilmiah, namun dalam pembelajaran tersebut guru masih dominan dan siswa kurang aktif; (2) pelaksanaan pengembangan karakter masih belum optimal. Hal tersebut dapat dilihat dari masih banyaknya siswa yang terlambat dalam mengumpulkan tugas, melihat jawaban teman, dan kurang sungguh-sungguh dalam mengerjakan tugas yang telah diberikan. Serta fenomena-fenomena dalam kehidupan sehari-hari seperti yang dilakukan masyarakat bantaran sungai baik di daerah perkotaan maupun desa, mereka terbiasa membuang libah rumah tangga disungai. Akitivitas tersebut merupakan sumber pencemaran yang akan menurunkan kualitas air, bahkan akan menjadi sumber timbulnya penyakit dan yang terburuk terjadi banjir akibat luapan air sungai akibat pendangkalan. Ternyata tidak sedikit dari pelakunya adalah orang yang terpelajar dan terdidik. Dalam hal ini, pendidikan memiliki peran dan tanggung jawab yang besar sebagai tempat untuk mendidik dan memperbaiki perilaku.

Berdasarkan permasalahan yang terkait dengan hasil pembelajaran serta harapan agar sikap siswa yang memiliki nilai-nilai karakter positif, maka kemungkinan perlu suatu perangkat pembelajaran yang dapat meningkatkan pengetahuan dan membantu siswa dalam mengembangkan sikap.

IPA terpadu dapat menggunakan isu-isu dan masalah di sekitar untuk dikemas menjadi tema pembelajaran (Sagala, 2011: 180). Tema pencemaran air membahas konsep mengenai; perubahan materi, campuran, larutan asam dan basa, serta pencemaran air. Siswa SMP masih sering mendapatkan pembelajaran IPA dengan konsep tersebut terpecah-pecah dalam bidang Kimia, Fisika, dan Biologi. Sebenarnya konsep-konsep tersebut saling berhubungan dan dapat dipadukan secara connected. Model connected adalah model pembelajaran IPA terpadu antar bidang studi yang secara nyata menghubungkan satu konsep dengan konsep lain, satu topik dengan topik lain, satu ketrampilan dengan ketrampilan lain, tugas yang dilakukan dalam satu hari berikutnya, serta ide-ide yang dipelajari pada satu semester dengan semester berikutnya (Forgaty, 1991).
Diharapkan dengan mengambil materi atau permasalahan yang muncul di sekitar lingkungan sekolah, dan menggunakan pendekatan scientific yang dikembangkan dengan kegiatan belajar melalui: (1) mengamati (membaca, mendengarkan, menyimak, dan melihat); (2) menanya (mengajukan pertanyaan tetang informasi yang tidak dipahami dari apa yang diamati atau pertanyaan untuk mendapatkan informasi tambahan tetang apa yang diamati); (3) mengumpulkan data (melakukan eksperimen, membaca sumber lain selain buku teks, mengamati objek/kajian); (4) mengasosiasi (mengolah informasi yang sudah dikumpulkan baik terbatas dari hasil kegiatan mengumpulkan/eksperimen maupun hasil dari kegiatan mengamati dan kegiatan mengumpulkan data); dan (5) mengomunikasikan (menyampaikan hasil pengamatan kesimpulan berdasakan hasil anlisa secara lisan, tertulis, atau media lain (Kemendikbud, 2013). Siswa dapat memperoleh pengalaman belajar secara langsung dengan itu akan menambah kekuatan untuk menerima, menyimpan, dan menerapkan konsep yang di pelajari secara menyeluruh. Serta siswa dimungkinkan akan lebih menghargai, mencitai, dan melestarikan lingkungan sekitar sebagai sumber kehidupan (Sagala, 2011). Hakekatnya akan membantu siswa mendapatkan sendiri pengetahuan, sikap, serta keterampilannya berdasarkan fakta dan observasi.

Beberapa hasil penelitian dengan menggunakan pembelajaran terpadu yang dilakukan oleh Turpin (2004), menyimpulkan bahwa pembelajaran terpadu yang diterapkan dapat meningkatkan hasil belajar siswa dan mengembangkan ketrampilan proses sains. Penelitian yang dilakukan oleh Listyawati (2012), menyimpulkan bahwa perangkat pembelajaran IPA dengan karakteristik berbasis lingkungan dapat meningkatkan kemampuan: kerjasama dengan kelompok, rasa percaya diri, kemampuan berpikir kritis, rasa ingin tahu kaitan materi yang lebih luas, mengembangkan respon yang tepat secara jujur, serta dapat meningkatkan penguasaan konsep siswa. Penelitian lain yang dilakukan oleh Opara (2011), menyimpulkan bahawa pembelajaran terpadu yang dilakukan dapat meningkatkan kompetensi dalam memecahkan masalah yang nyata. Berdasarkan uraian di atas, maka timbul suatu pertanyaan: bagaimana kelayakan perangkat pembelajaran IPA terpadu tipe connected yang dikembangkan pada pokok bahasan pencemaran air untuk meningkatkan hasil belajar siswa SMP? Untuk mendapatkan jawaban, peneliti merencanakan mengadakan penelitian dengan judul "Pengembangan Perangkat Pembelajaran IPA Terpadu tipe Connected Pokok Bahasan Pencemaran Air dengan Sumber Belajar Lingkungan Sekitar pada Siswa SMP”. 


\section{METODE}

Penelitian ini merupakan penelitian pengembangan, karena mengembangkan perangkat pembelajaran yang dikembangkan meliputi: rencana pelaksanaan pembelajaran (RPP), buku siswa, lembar kerja siswa (LKS), tes hasil belajar (THB). Model pengembangan perangkat dalam penelitian ini menggunakan model Dick and Carey. Pengambilan data dilaksanakan pada semester genap tahun pelajaran 2013/2014 dengan subyek penelitian adalah siswa kelas VII, sebanyak 32 siswa.

Desain penelitian menggunakan One Group Pretest-Postest Design, dengan bentuk desain sebagai berikut (Tuckman, 1986):
$\mathrm{O}_{1}$
$\mathrm{X}$
$\mathrm{O}_{2}$
Pretest
Perlakuan
Postest

Keterangan:

$\mathrm{O}_{1} \quad$ : Pretest, pemberian pretest untuk mengetahui kemampuan awal siswa

X : Perlakuan, pembelajaran dengan menggunakan Perangakat IPA terpadu tipe connected dengan sumber belajar lingkungan sekitar.

$\mathrm{O}_{2} \quad$ : Postest, pemberian postest untuk mengetahui hasil belajar pengetahuan siswa setelah dilakukan pembelajaran.

Variabel yang diamati dalam penelitian adalah (1) Validitas RPP, LKS BA,S dan THB; (2) variabel yang berkaitan dengan hasil ujicoba perangkat pembelajaran meliputi: validitas perarngkat, keterlaksanaan RPP, hasil belajar pengetahuan, hasil belajar ketrampilan, hasil belajar sikap, respons siswa dan kendala yang muncul dalam KBM.

Instrumen yang digunakan dalam penelitian ini adalah instrumen penilaian perangkat, instrumen pengmatan, instrument tes, dan instrument angket. Data yang dianalisis adalah validitas perangkat, keterlaksanaan RPP, hasil belajar pengetahuan, hasil belajar ketrampilan, hasil belajar sikap, respon siswa dan kendala yang muncul dalam KBM dengan menggunakan teknik analisis dan deskriftif kuantitatif.

\section{HASIL DAN PEMBAHASAN}

Berdasarkan hasil penelitian, diperoleh data terkait validitas perangkat pembelajaran meliputi: RPP, LKS, materi ajar, dan THB, keterlaksanaan rencana pembelajaran, hasil belajar pengetahuan siswa, hasil belajar ketrampilan, hasil belajar sikap respon siswa, dan kendala selama pembelajaran.

\section{Hasil Validitas Perangkat Pembelajaran}

Berdasarkan hasil validitas, perangkat yang dikembangkan dalam penelitian ini adalah RPP, LKS, materi ajar dan THB. Berdasarkan rata-rata nilai validasi kelayakan RPP dari dua validator mendapatkan rata-rata skor 4,00 dengan kategori baik, karena perangkat yang dikembangkan sesuai dengan tujuan pembelajaran, kegiatan pembelajaran, waktu, metode penyajian dan bahasa yang digunakan mudah dipahami oleh siswa.

Hasil penilaian kelayakan materi ajar secara keseluruhan menunjukkan bahwa kedua validator memberikan rata-rata skor 4,00 dengan kategori baik.

Perangkat pembelajaran yang dikembangkan merupakan salah satu faktor yang menentukan tercapai atau tidaknya tujuan pembelajaran. Perangkat pembelajaran yang baik akan menentukan kualitas pembelajaran. Pengembangan perangkat pembelajaran yang dilakukan sesuai dengan teori scaffolding yang dicetuskan Vygotsky (dalam Slavin, 2006), yaitu pengembangan perangkat pembelajaran dapat memberikan umpan balik kepada siswa untuk meningkatkan potensialnya. Perangkat yang dikembangkan mendorong tingkat perkembangan aktual siswa melalui kemampuan memecahkan masalah secara mandiri dan tingkat perkembangan potensi melalui pemecahan masalah di bawah bimbingan guru atau kerjasama dengan teman sebaya.

Hasil penilaian kelayakan LKS secara keseluruhan menunjukkan bahwa kedua validator memberikan ratarata skor 4,00 dengan kategori baik. Hal ini dikarenakan LKS yang dikembangkan memiliki aspek petunjuk yang jelas, isi sesuai dengan materi yang diajarkan, prosedur kerja yang sistematis, kesesuaian pertanyaan

Hasil penilaian THB masing validator memberikan nilai valid tanpa revisi dan beberapa soal mendapatkan kategori valid dengan revisi, hal tersebut menunjukkan bahwa tes hasil belajar yang dikembangkan layak digunakan sebagai instrument penilaian hasil belajar siswa. Instrumen peneliti adalah alat atau fasilitas yang digunakan oleh peneliti dalam pengumpulan data agar pekerjaannya lebih mudah dan hasilnya lebih baik, dalam arti lebih cermat, lengkap, dan sistematis, sehingga lebih mudah diolah (Arikunto, 2002), dengan demikian instrumen dengan validitas baik, maka akan menjadi layak digunakan untuk memperoleh data penelitian.

\section{Keterlaksanaan Rencana Pembelajaran}

Hasil pengamatan keterlaksanaan RPP mendapat rata-rata skor keterlaksanaan berdasarkan kegiatan pembuka, inti, kegiatan pemantapan, penutup, dan suasanakelas, selama tiga kali pertemuan dapat terlaksana dengan baik.

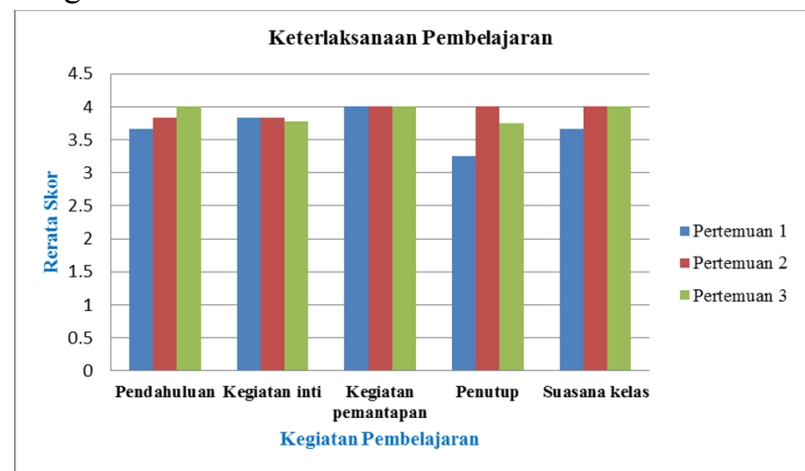

Gambar 1. Grafik hasil keterlaksanaan rencana pembelajaran 
Aspek yang diamati secara keseluruhan meliputi kegiatan pendahuluan, kegiatan inti, kegiatan pemantapan, penutup dan suasana kelas. Pengamatan kegiatan pembelajaran pada tahap pendahuluan merupakan fase pertama dalam pembelajaran, dalam hal ini guru melakukan apersepsi atau mengaitkan materi sebelumnya dengan materi yang akan dipelajari, selanjutnya guru secara aktif memotivasi siswa untuk fokus dalam kegiatan belajar mengajar dan menyampaikan tujuan pembelajaran yang akan dicapai selama kegiatan pembelajaran. Pada pelaksanaan kegiatan inti merupakan proses pembelajaran untuk pencapaian tujuan pembelajaran. Pada fase kegiatan inti guru melakukan menyajikan informasi, menjelaskan dan memberikan contoh pemakain alat dan bahan yang akan digunakan, bembimbing pembentukan kelompok, menyediakan permasalahan, membimbing siswa dalam membuat pertanyaan yang berkaitan dengan materi, membimbing siswa dalam merancang percobaan, membimbing siswa dalam melakukan percobaan, dan membimbing siswa dalam mengumpulkan dan menganalisis data, serta membimbing siswa dalam diskusi kelompok. Kegiatan pemantapan yang dilakukan guru dalam hal ini adalah melakukan pengecekan pemahaman siswa dari semua materi yang telah dipelajari. Kegaitan penutup yang telah dilakukan oleh guru terdiri dari membimbing siswa dalam membuat kesimpulan, memberikan permasalahan sebagai penerapan dengan cara memberikan tugas rumah sebagai latihan mandiri. Pada kegiatan pengamatan suasana kelas yang terdiri dari pengamatan kesusuaian waktu dengan alokasi waktu, antusias siswa, dan antusias guru.

Berdasarkan hasil pengamatan keterlaksanaan pembelajaran oleh pengamat menyatakan bahwa seluruh tahapan pembelajaran terlaksana secara keseluruhan dengan skor rata-rata 3,67 dengan kategori baik.

Hasil reliabilitas instrumen keterlaksanaan pembelajaran secara keseluruhan $85 \%$, dalam hal ini bisa diasumsikan bahwa instrumen yang digunakan masih reliabel. Instrumen keterlaksanaan pembelajaran dikatakan reliabel, apabila releabilitasnya $\geq 75 \%$ (Borich, 1994 dalam Ibrahim, 2005). Hal ini menunjukkan bahwa intrumen keterlaksanaan pembelajaran yang telah dibuat memiliki konsistensi atau keajegan dalam mengukur keterlaksanaan pembelajaran selama pembelajaran. Perancangan perangkat pembelajaran yang disusun sesuai dengan teori scaffolding yang diungkapkan oleh Vygotsky, yaitu tingkat perkembangan aktual anak ditentukan oleh kemampuan memecahkan masalah secara mandiri dan tingkat perkembangan potensi ditentukan oleh pemecahan masalah di bawah bimbingan guru atau kerjasama dengan teman sebaya. Bimbingan atau bantuan tersebut dapat berupa petunjuk, peringatan, dorongan, menguraikan, masalah kedalam langkah-langkah pemecahan, memberikan contoh ataupun yang lain sehingga memungkinkan siswa tumbuh mandiri (Slavin, 2006).

\section{Hasil Belajar Pengetahuan Siswa}

Hasil belajar siswa ini dibedakan menjadi dua, yaitu pretest dan posttest, hal ini digunakan agar dapat mengetahui peningkatan hasil belajar pengetahuan setiap siswa. Pretest diberikan sebelum perlakuan, sedangkan posttest diberikan setelah perlakuan.

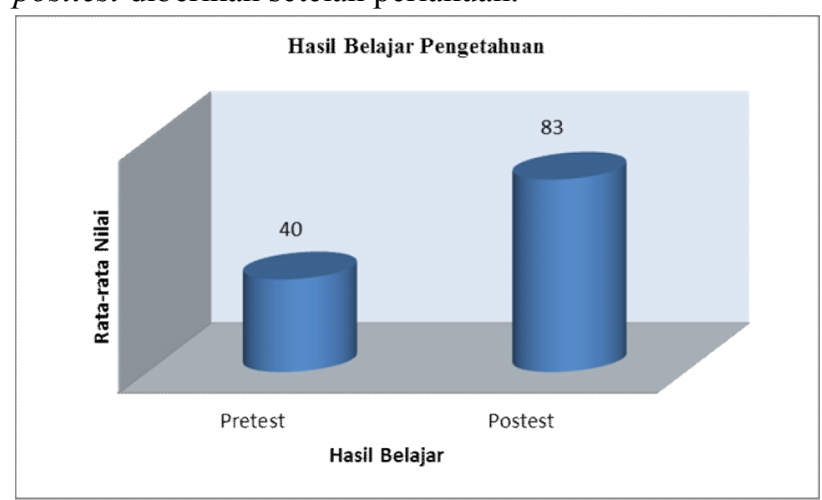

Gambar 2. Rata-rata nilai tes hasil belajar pengetahuan

Ketetapan Kriteria Ketuntasan Minimal (KKM) untuk mata pelajaran IPA SMP Negeri 1 Sedati Sidoarjo adalah $\geq 0,70$. Sehingga siswa dianggap tuntas jika proporsi hasil pengetahuan belajarnya mencapai 0,70 .

Hasil yang diperoleh, dapat dikemukakan bahwa pelaksanaan pretest dengan objek penelitian 32 siswa mendapatkan rata-rata nilai di bawah KKM, dapat dikatakan bahwa nilai pretest siswa tidak ada yang tuntas. Pada pelaksanaan posttest seluruh siswa dapat mencapai KKM atau dapat dikatakan tuntas. Maka keseluruhan sampel tersebut dapat dikatakan tuntas secara klasikal. Berdasarkan Gambar 2 menunjukkan adanya peningkatan kemampuan pengetahuan siswa ini terlihat dari rata-rata nilai pretest dan posttest yaitu 40,00 dan 83,13. Peningkatan rata-rata tes hasil belajar ini merupakan pengaruh dari pembelajaran yang diberikan. Hal ini sesuai dengan pengukuran indeks sensitivitas tiap butir soal yang menunjukkan bahwa indeks sensitivitas pada soal yang dikembangkan secara rata-rata 0,43 . Ini menunjukkan bahwa butir soal tersebut memiliki kepekaan terhadap efek pembelajaran yang diberikan. Hal ini menunjukkan bahwa peningkatan hasil belajar siswa setelah diberikan perlakuan merupakan efek dari perlakuan dengan perangkat pembelajaran IPA terpadu tipe connected dengan sumber belajar lingkungan sekitar yang diberikan. Untuk mengetahui bahwa jawaban yang mereka berikan merupan bentuk penguasaan konsep dari siswa, maka hasil tes belajar ini juga dianalisis dengan menggunakan Gain Score yang ternomalisasi (N-Gain). Bedasarkan hasil N-Gain menunjukkan bahwa skor ratarata gain yang tinggi yaitu 0,71. Hal tersebut, menunjukkan bahwa kemampuan penguasaan konsep siswa yang telah mengikuti pembelajaran dengan perangkat pembelajaran IPA terpadu tipe connected 
dengan sumber belajar lingkungan sekitar yang dikembangkan telah mengalami peningkatan secara efektif. Selain untuk mengetahui penguasaan konsep siswa, analisis N-Gain ini juga dapat menunjukkan adanya perbedaan antara sesudah dan sebelum diberikan perlakuan. Hal ini sesuai dengan Hake (1998), bahwa gain score ternomalisasi yang tinggi menunjukkan tingkat efektifitas.

\section{Hasil Belajar Ketrampilan}

Hasil belajar ketrampilan yang diamati dari hasil pembelajaran adalah membuat tabel hasil pengamatan, menggunakan kertas lakmus untuk mengetahui sifat larutan, melakukan penjernihan air dengan filtrasi sederhan, dan melakukkan penjernihan air dengan destilasi.

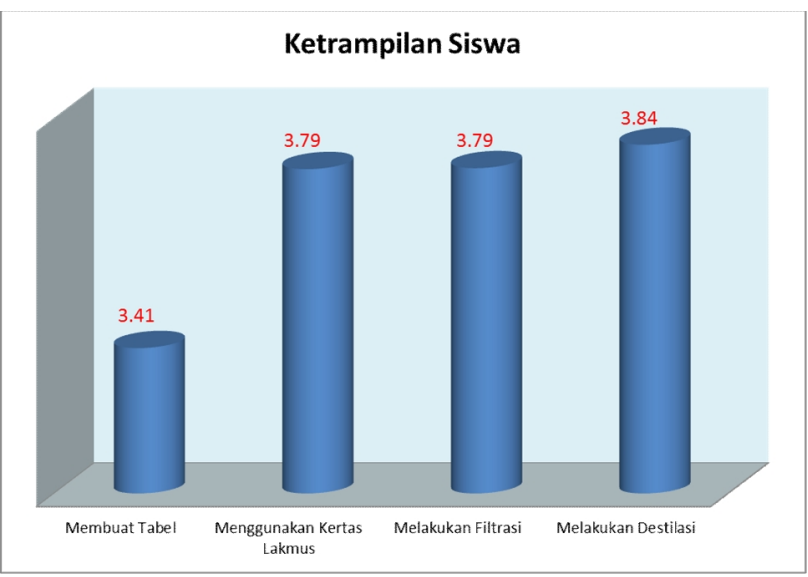

Gambar 3. Hasil belajar ketrampilan siswa

Aspek yang diamati dalam penilaian pembuatan tabel hasil pengamatan yaitu tabel data mengandung data yang cocok dengan hasil pengamatan, informasi di dalam kolom tabel telah diorganisasi dengan sesuai dan diberi judul, unit pengukuran semua informasi ditunjukkan dengan jelas, dan tabel teratur dan diberi judul. Pada aspek pembuatan tabel hasil pengamatan tersebut mendapatkan skor rata-rata 3.41 dalam artian siswa dapat membuat tabel hasil pengamatan dengan baik.

Aspek yang diamati dalam menggunakan kertas lakmus untuk mengetahui sifat larutan yaitu memasukkan sebagian kertas lakmus merah dan biru pada sampel larutan uji, menentukan perubahan warna kertas lakmus merah dan biru, dan menentukan sifat larutan sampel. Hasil pengamatan menggunakan kertas lakmus siswa mendapatkan rata-rata skor 3,79 alam artian siswa dapat melakukan dengan sangat baik. Namun terdapat beberapa siswa yang masih kesulitan membedakan sifat larutan, hal tersebut terjadi karena perubahan kertas lakmus yang masih sulit dibedakan.

Aspek yang diamati dalam melakukan penjernihan air dengan filtrasi sederhana yaitu memotong bagian bawah botol air mineral, mencuci pasir dan kerikil hingga terbebas dari tanah, memasukkan kapas/tissue, kerikil, dan pasir ke dalam botol, memasukkan air kotor kedalam botol, dan menampung air yang menetes ke mulut botol. Berdasarkan pengamatan ketrampilan siswa melakukan filtrasi sederhana siswa rata-rata mendapatkan skor 3,79 dalam artian dapat dilakukan dengan sangat baik oleh siswa. Namun pada aspek ini ada beberapa siswa mencuci pasir dan kerikil masih kurang bersih, sehingga mempengaruh hasil filtrasi.

Aspek yang diamati dalam melakukan penjernihan air dengan destilasi yaitu memasukkan air kotor ke dalam labu erlenmeyer $100 \mathrm{ml}$, menutup labu dengan sumbat gabus dan pipa penghubung dan mehubungkan dengan pendingin (kondensor), mengalirkan air ke dalam pendingin secara terus-menerus, memanaskan labu sampai air kotor mendidih, dan menampung cairan yang menetes dari pendingin dengan tabung reaksi. Dari hasil pengamatan ketrampilan melakukan destilasi rata-rata siswa diperoleh skor 3,84 dalam artian dapat dilakukan dengan sangat baik oleh siswa. Selama kegiatan eksperimen guru tidak membiarkan siswa begitu saja, tetapi guru bertindak memberikan bimbingan. Guru melakukan bimbingan belajar untuk memastikan agar siswa mengalami keberhasilan pada saat siswa menerapkan konsep atau keterampilan yang baru.

\section{Hasil Belajar Sikap}

Hasil belajar sikap yang diimplementasikan dalam pembelajaran meliputi sikap spiritual dalam penelitian ini yaitu mengagumi ciptaan Tuhan, dan sikap sosila yaitu jujur, tanggung jawab, serta peduli lingkungan.

\section{a. Skap spiritual}

Aspek sikap spiritual mengagumi ciptaan Tuhan dalam penelitian ini yang diamati yaitu menyadari dan meyakini ciptaan Tuhan.

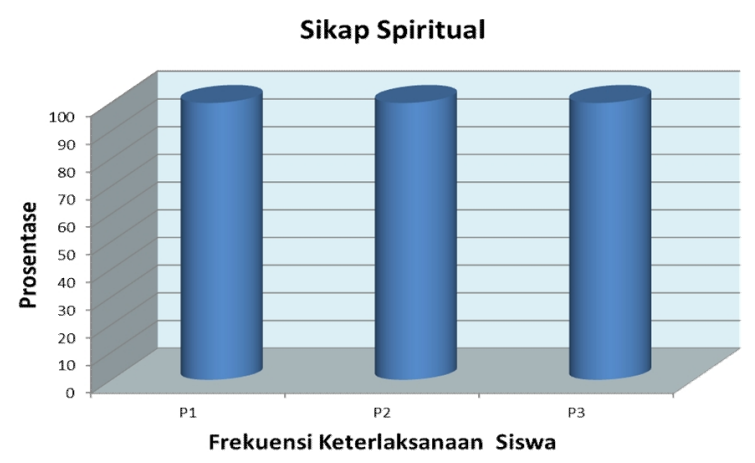

Gambar 4. Hasil pengamtan sikap spiritual mengagumi ciptaan Tuhan

Berdasarkan Gambar 4. menunjukkan rata-rata prosentase sikap spiritual mengagumi ciptaan Tuhan dengan indikator menyadari dan meyakini ciptaan Tuhan selama 3 kali pertemuan mendapatkan 100\%. Hal ini menunjukkan bahawa pembelajaran IPA terpadu tipe connected dengan sumber belajara lingkungan sekitar, dapat mengembangkan sikap spiritual mengagumi ciptaan Tuhan. Apabila pembelajaran dilakukan secara konsisten dimungkinkan dapat mengembangkan karakter spiritual yang diinginkan. 


\section{b. Sikap sosial jujur}

Aspek sikap sosial jujur yang diamati dalam penelitian ini adalah mencatat hasil pengamatan sesuai dengan yang diamati, menyampaikan pendapat sesuai dengan data pengamatan, dan tidak mencontek dari pekerjaan teman.

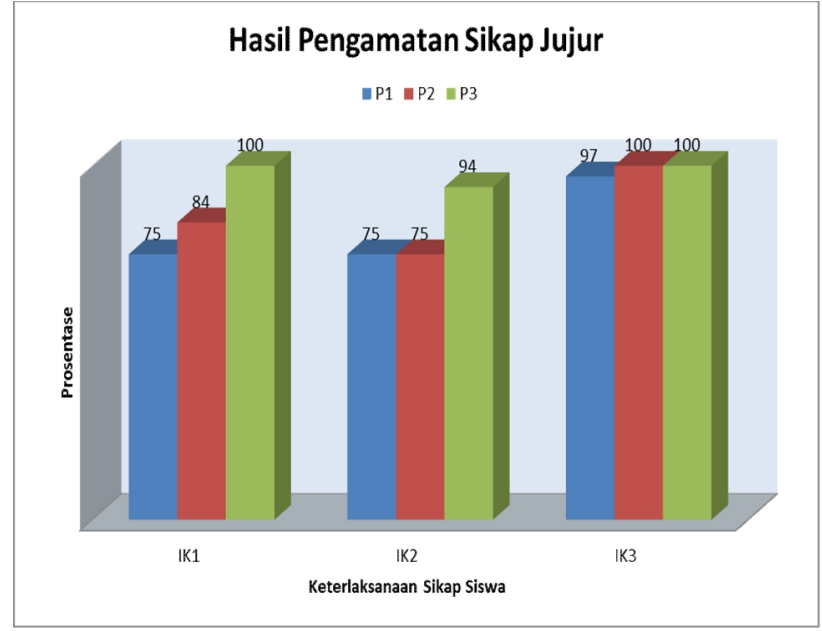

Gambar 5. Hasil pengamtan sikap sosial jujur

Indikator aspek sikap sosial jujur yang diamati dalam penelitian ini yang pertama adalah mencatat hasil pengamatan sesuai dengan yang diamati. Dari hasil pengamatan selama tiga kali pertemuan, pada pertemuan pertama terdapat $75 \%$ siswa yang memperlihatkan indikator sikap jujur, pertemuan kedua $84 \%$ siswa yang memperlihatkan indikator sikap jujur, dan pertemuan ketiga terdapat $100 \%$ siswa yang memperlihatkan indikator sikap jujur. Sedangakan indikator sikap sosial jujur yang kedua adalah menyampaikan pendapat sesuai dengan data pengamatan. Dari pengamatan didapatkan pada pertemuan pertama dan kedua terdapat $75 \%$ siswa yang memperlihatkan indikator sikap jujur, dan pada pertemuan ketiga terdapat $94 \%$ siswa yang memperlihatkan indikator sikap jujur. Indikator sikap sosial jujur yang ketiga adalah tidak mencontek dari pekerjaan teman. Dari pengamatan didapatkan, pertemuan pertama terdapat $84 \%$ siswa yang memperlihatkan indikator sikap jujur, pertemuan kedua terdapat $94 \%$ siswa yang memperlihatkan indikator sikap jujur, dan pada pertemuan ketiga terdapat 97\% siswa yang memperlihatkan indikator sikap jujur. Dari data hasil pengamatan (Gambar 5.) menunjukkan bahwa frekuensi siswa yang memperlihatkan indikator sikap jujur lebih dari $70 \%$ siswa yang memeperlihatkan indikator sikap jujur. Hal tersebut dapat dikatakan bahwa pembelajaran IPA terpadu tipe connected dengan sumber belajara lingkungan sekitar, dapat mengembangkan sikap sosial jujur. Apabila pembelajaran dilakukan secara konsisten dimungkinkan dapat mengembangkan karakter sosial jujur yang ingin dikembangkan.

\section{c. Sikap sosial tanggung jawab}

Aspek sikap sosial tanggung jawab yang diamati adalah mengembalikan alat dan bahan yang dibutuhkan saat praktikum ke tempat semula, melaksanakan tugas sesuai dengan kemampuan, dan berani menyampaikan hasil pengamatan atau diskusi kelas.

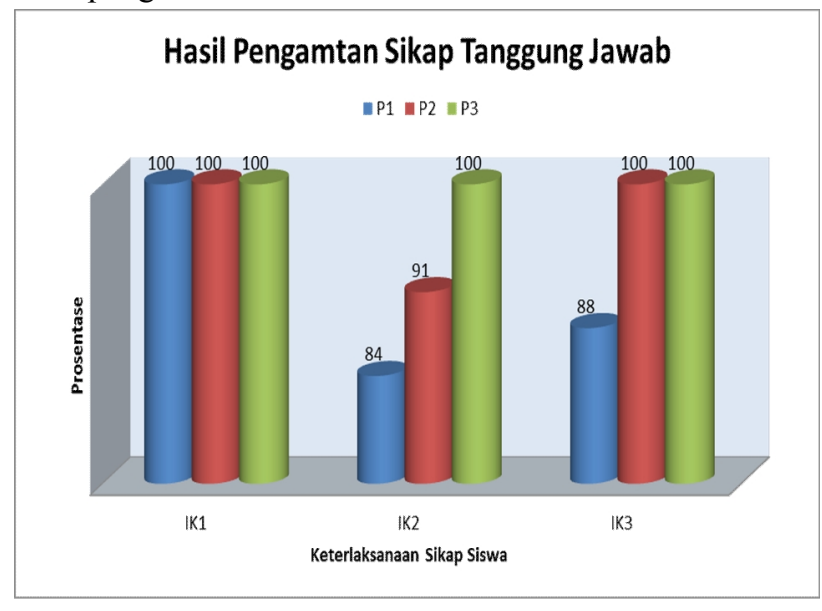

Gambar 6. Hasil pengamtan sikap sosial tanggung jawab

Indikator aspek sikap sosial tanggung jawa yang diamati dalam penelitian ini yang pertama adalah mengembalikan alat dan bahan yang dibutuhkan saat praktikum ke tempat semula. Dari hasil pengamatan didapatkan, pada pertemuan pertama samapai pertemuan ketiga terdapat 32 sampel siswa seluruhnya memperlihatkan sikap sosila tanggung jawab, dari jumlah frekuensi tersebut dikatakan bahawa 100\% seluruh siswa melakukan indikator sikap sosial tanggung jawab yang dikembangkan. Pada indikator aspek sosial tanggung jawab yang kedua adalah melaksanakan tugas sesuai dengan kemampuan. Dari hasil pengamatan didapatkan, pertemuan pertama terdapat $84 \%$ siswa melakukan indikator sikap sosial tanggung jawab, pertemuan kedua terdapat $91 \%$ siswa yang memperlihatkan indikator sikap sosial tanggung jawab, sedangkan pada pertemuan ketiga terdapat $100 \%$ siswa yang memperlihatkan indikator sikap sosial tanggung jawab. Indikator sikap sosial tanggung jawab yang ketiga adalah berani menyampaikan hasil pengamatan atau diskusi kelas. Dari hasil pengmatan didapatkan, pada Pertemuan pertama terdapat $88 \%$ siswa yang memperlihatkan indikator sikap sosial tanggung jawab, sedangkan pada pertemuan kedua dan ketiga terdapat 100\% siswa yang memperlihatkan indikator sikap sosial tanggung jawab. Dari data hasil pengamatan (Gambar 6.) menunjukkan bahwa frekuensi siswa yang memperlihatkan indikator sikap tanggung jawab dapat dikatakan lebih dari 70\% siswa yang memeperlihatkan indikator sikap sosial tanggung jawab. Hal tersebut dapat dikatakan bahwa pembelajaran IPA terpadu tipe connected dengan sumber belajar lingkungan sekitar, dapat mengembangkan sikap sosial tanggung jawab. Apabila pembelajaran dilakukan secara konsisten dimungkinkan dapat mengembangkan 
karakter sosial tanggung jawab yang ingin dikembangkan.

\section{d. Sikap sosial peduli lingkungan}

Aspek sikap sosial peduli lingkungan yang diamati adalah membersihkan ruangan kelas sebelum pelajaran, membuang samapah pada tempatnya dan memungut sampah yang terdapat dilingkungan sekitar.

\section{Hasil Pengamatan Sikap Peduli LIngkungan}

- $\mathrm{P} 1=\mathrm{P} 2=\mathrm{P} 3$

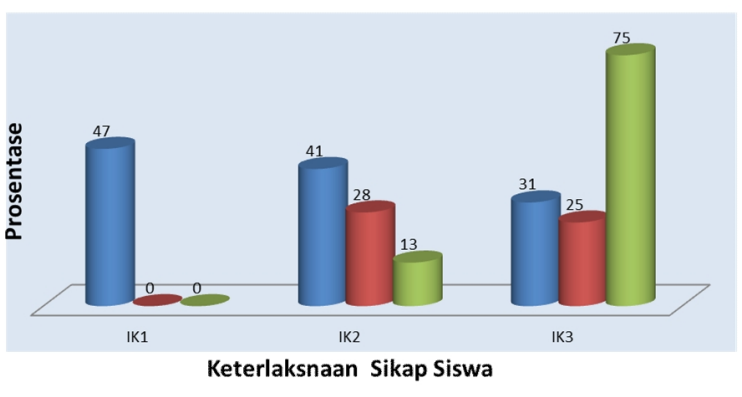

Gambar 7. Hasil pengamtan sikap peduli lingkungan

Indikator aspek sikap sosial peduli lingkungan yang diamati dalam penelitian ini yang pertama adalah membersihkan ruangan kelas sebelum pelajaran. Dari hasil pengamatan didapatkan, pada pertemuan pertama terdapat $47 \%$ siswa yang memperlihatkan indikator siskap sosial peduli lingkungan, pada pertemuan pertama keadaan ruang kelas sebelum digunakan untuk belajar cukup kotor, sehingga beberapa siswa sebelum pembelajaran membersihkan ruangan terlebih dahulu, sedangkan pada hari kedua dan ketiga tidak ada siswa yang memperlihatkan indikator sikap sosial peduli lingkungan. Hal tersebut disebabkan karena keadaan ruangan cukup bersih sehingga kondusif digunakan untuk pembelajaran sehingga indikator sikap sosial peduli lingkungan yang dikembangkan tidak terlihat atau tidak teramati. Indikator sikap sosial peduli lingkungan yang kedua adalah membuang samapah pada tempatnya. Dari hasil pengamatan didapatkan, pada pertemuan pertama $41 \%$ siswa memperlihatkan indikator sikap sosial peduli lingkungan, pertemuan kedua $28 \%$ siswa memperlihatkan indikator sikap sosial peduli lingkungan dan pertemuan ketiga $13 \%$ siswa memperlihatkan indikator sikap sosial peduli lingkungan. Pada hari pertama sampai hari ketiga frekuensi siswa yang memperlihatkan indikator sikap sosial peduli lingkungan semakin menurun, hal ini dikarenakan siswa berada di keadaan kelas yang bersih, sehingga indikator sikap sosial peduli lingkungan tidak teramati. Dan indikator sikap sosial yang ketiga adalah memungut sampah yang terdapat dilingkungan sekitar. Dari hasil pengamatan didapatkan, pada pertemuan pertama terdapat $31 \%$ siswa yang memeperlihatkan indikator sikap sosial peduli lingkungan, pada pertemuan kedua terdapat $25 \%$ yang memeperlihatkan indikator sikap sosial peduli lingkungan, dan pada pertemuan ketiga terdapat $75 \%$ siswa yang memeperlihatkan indikator sikap sosial peduli lingkungan. Pada hari pertama dan kedua frekuensi siswa yang memperlihatkan indikator sikap sosial peduli lingkungan yang sedikit, dikarenakan keadaan kelas cenderung bersih. Sedangkan pada hari ketiga terdapat frekuensi siswa yang memeperlihatkan indikator sikap sosial peduli lingkungan lebih banyak karena bekas sampah dari praktikum pada hari ketiga cenderung lebih banyak, sehingga siswa memeperlihatkan indikator sikap sosial peduli lingkungan. Pada pengembangan sikap sosial peduli lingkungan dengan pembelajaran yang dilakukan cukup sulit karena berkaitan dengan keadaan lingkungan sekitar, ketika keadaan lingkungan kotor maka dimungkinkan sikap sosial peduli lingkungan dapat dikembangkan. Sehingga apabila pembelajaran dengan perangkat yang dikembangkan secara konsisten dimungkinkan dapat mengembangkan karakter sosial peduli lingkunga yang ingin dikembangkan.

\section{Respon Siswa}

Respon siswa diukur menggunakan angket, yang diberikan pada 32 siswa, bahwa 84,38\% siswa menyatakan pembelajaran yang dilakukan menarik bagi siswa. Tetapi terdapat $15,62 \%$ yang menyatakan bahwa pembelajaran yang dilakukan tidak menarik bagi siswa. Berdasarkan respon siswa bahwa pembelajaran ini menumbuhkan rasa ingin tahu siswa (93,75\%) dan menyenangkan $(93,76 \%)$. Hal ini dimungkinkan kegiatan pembelajaran dan kegiatan dalam LKS yang membuat siswa termotivasi untuk menumbuhkan rasa ingin tahu siswa dalam proses pembelajaran. Dalam hal ini, prosentase respon siswa $10,94 \%$ ragu-ragu, 57,23 siswa puas dan $31,25 \%$ siswa sangat puas terhadap pembelajaran yang diajarakan dengan perangkat yang dikembangkan.

Respon siswa juga menunjukkan bahwa siswa terbantu dalam memahami materi secara menyeluruh dengan prosentase respon siswa sebesar $86,88 \%$. Ini menunjukkan bahwa pembelajaran dengan perangkat pembelajaran IPA terpadu tipe connected dengan sumber belajar lingkungan sekitar dapat membantu memahami materi secara menyeluruh. Jika dilihat dari LKS yang telah dikembangkan, 93,75\% siswa menyatakan bahwa LKS yang dikembangkan baru bagi siswa. Kegiatan dalam LKS dengan pendekatan sainstific yang dikembangkan membantu siswa dalam menyelesaikan masalah yaitu 90,63\% respon siswa. Hal ini didukung dengan pertanyaan yang diajukan mudah dipahami oleh siswa mendapatkan 96,88\% respon dari siswa.

Berdasarkan respon siswa tersebut dapat dikatakan bahwa perangkat pembelajaran dan kegiatan pembelajaran IPA terpadu tipe connected dengan sumber belajar lingkungan sekitar yang digunakan oleh guru terlihat bahwa siswa senang dan berminat untuk belajar, dan siswa yang termotivasi dalam pembelajaran akan memperlihatkan ciri-ciri senang dan antusias belajar.

\section{Kendala Selama Pembelajaran}

Secara umum dalam pembelajaran berlangsung dengan baik, namun terdapat beberapa hambatan di dalam 
pembelajaran dan perlu mendapatkan perhatian. Hambatan tersebut merupakan akibat dari belum terbiasanya siswa dalam kegiatan observasi dan pengamatan. Pembelajaran dengan melakukan kegiatan observasi dan pengamatan di luar kelas jarang dialami oleh siswa, sehingga pengelolaan waktu tidak sesuai dengan alaokasi waktu yang di tentukan. Solusinya adalah guru harus dapat mengefesienkan waktu yang ada dengan banyak memonitoring kegiatan siswa terutama pada saat berada di luar kelas.

Guru harus terus mengingatkan kepada siswa untuk berbagi tugas dan bekerja sama dalam kelompok sehingga waktu dapat diefesiensikan. Hal ini sejalan dengan teori Vigotsky yang menyatakan bahwa pemberian bimbingan harus disegerakan. Pemberian bimbingan dilakukan selama pembelajaran dengan mengurangi intensitas pemberian bimbingan agar siswa dapat mengambil perannya untuk mengembangkan ideide mereka.

\section{PENUTUP \\ Simpulan}

Berdasarkan hasil analisis data yang kemudian dideskripsikan pada diskusi hasil penelitian, maka dapat dibuat kesimpulan perangkat pembelajaran IPA terpadu tipe connected pokok bahasan pencemaran air layak dan dapat meningkatkan hasil belajar siswa.

\section{Saran}

Berdasarkan hasil penelitian yang telah dilakukan, disarankan sebagai berikut:

1. Perangakat pembelajaran yang dikembangkan dapat digunakan sebagai alternatif untuk meningkatkan hasil belajar siswa pada materi IPA yang terkait.

2. Pengelolaan waktu dan persiapan perlu diperhatikan, agar pembelajaran dapat terlaksana dengan baik.

3. Dalam mengembangkan sikap siswa perlu diadakan lingkunga yang mendukung, sehingga siswa dapat memperlihatkan indikator sikap yang diamati.

\section{DAFTAR PUSTAKA}

Afianti, R., Hartati, S., \& Sawitri., D. R. (2010). Aqib, Z., \& Sujak. 2011. Panduan dan Aplikasi Pendidikan Karakter. Bandung: Yarma Widya.

Arends, R. I. 2012. Learning to Teach. Ninth Edition. New York: The Mc Graw-Hill Companies.

Arikunto, S. 2002. Dasar-dasar Evaluasi Pendidikan. Jakarta: Bumi Aksara.

Arikunto, S. 2010. Prosedur Penelitian Suatu Pendekatan Praktik. Jakarta: Rineka Cipta.

Brady, J. E. 2008. Kimia Universitas Asa dan Struktur, jilid dua. Tangerang: Binarupa Aksara.

Chang, R. 2003. General Chemestry; The Essential Concepts, Edition 3. New York: McGraw-Hill.

Dick, W., \& Carey, L. 1990. The Systematic Design of Instruction. Florida State: Haper Collins Publishers.
Forgaty, R. 1991. The Mindful School: How to Integreate the Curricula. America: Skylight Publishing, inc.

Hake, R.R. 1998. Analyzing Change/Gain Scores. USA: Indiana University.

Ibrahim, M. 2002. Pelatihan Terintegrasi Berbasis Kompetensi. Jakarta: Depdiknas.

Ibrahim, M. 2010. Dasar-dasar Proses Belajar Mengajar. Surabaya: Unesa University Press.

Ibrahim, M. 2012. Konsep, Miskonsepsi dan Cara Pembelajarannya. Surabaya:Unesa University Press.

Keenan, C. W., Kleinfelter, D. C., \& Wood, J. H. 1990. General College Chemistry, Sixth Edition. Harper \& Row, Publisher, Inc.

Kemendikbud. 2013 a. Kurikulum 2013 dan Implementasinya. Lampiran V. Jakarta: Kementrian Pendidikan dan Kebudayaan.

Kemendikbud. 2013 b. Konsep Pembelajaran IPA Terpadu. Jakarta: Kementrian Pendidikan dan Kebudayaan.

Kemp, J., Steven, R., \& Gary, M. 2007. Designing Effective Instruction. USE: Jonh Wiley \& Sons, Inc.

Lazim, M. 2013. Penerapan Pendekatan Saintifik dalam Pembelajaran Kurikulum 2013. Jakarta: DIKTI.

Lickona, T. 2012. Mendidik untuk Membentuk Karakter. Jakarta: Bumi Aksara.

Lin, Lih Juan Chan. 2008. Technology integration applied to project-based learning in science. Innovations in Education and Teaching International. Vol. 45, No. 1, pp 55-65.

Listyawati, M. 2012. Pengembangan Perangkat IPA Terpadu di SMP. Journal of Innovative Science Education. pp 62-69.

Muhlisin, A. 2012. Pengembangan Perangkat Pembelajaran Ipa Terpadu. Journal of Educational Research and Evaluation. pp 139-145.

Mulyasa. 2013. Pengembangan dan Implementasi Kurikulum 2013. Bandung: Remaja Rosdakarya.

Nisak, K. 2013. Pengembangan Perangkat Pembelajaran Ipa Terpadu Tipe Connected. Jurnal Pendidikan Sains e-Pensa. hal 81-84.

Nur, M. 1998. Teori Pembelajaran Kognitif. Surabaya: UNESA Press.

Olomouc. 2008. European Dimension in Integrated Science Education, Training Material for Students. UDK.

Opara, Jacinta A. 2011. Bajah's Model and the Teaching and Learning of Integrated Science in Nigerian High School System. International Journal of Academic Research in Business and Social Sciences, August 2011, Vol. 1, pp 152-161.

Puskur. 2007. Panduan Pengembangan Pembelajaran IPA Terpadu, Sekolah Menengah 
Pertama/Madrasah Tsanawiyah (SMP/MTs). Jakarta: Balitbang Depdiknas.

Poerwati, L. E., \& Amri. 2013. Panduan Memahami Kurikulum 2013. Jakarta: Prestasi Pustaka.

Sagala, S. 2011. Konsep dan Makna Pembelajaran. Bandung : Alfabeta.

Sanagi, M. M. 2001. Teknik Pemisahan dalam Analisis Kimia. Malaysia: Universitas Teknologi Malaysia.

Slavin, R. E. 2006. Educational psychology: Theory and Practise. Eighth edition. Massachusetts: Allyn and Bacon.

Slavin, R. E. 2011. Psikologi Pendidikan Teori dan Praktik Edisi Kesembilan. Jakarta: PT Indeks.

Sudjana, N. 2012. Penilaian Hasil Proses Belajar Mengajar. Bandung: Remaja Rosdakarya.

Sultoni. 2011. Pengembangan Perangkat Pembelajaran Terpadu Tipe Webbed pada Konsep Gerak Melingkar untuk SMK Kelas X. Tesis. Tidak Dipublikasikan: UNESA.

$\mathrm{Su}$, King Dow. 2011. An intensive ICT-integrated Environmental Learning Strategy for Enhancing Student Performance. International Journal of Environmental \& Science Education. Vol. 6, No. 1, pp 39-58.

Supranoto, T. H. 2007. Pengaruh Implementasi Pembelajaran Terpadu Tipe Connected terhadap Kinerja Ilmiah Siswa dan Ketuntasan Belajar Siswa di SMP. Makalah Komprehensif. Tidak Dipublikasikan: UNESA.

Syukri. 1999. Kimia Dasar 2. Bandung: ITB.

Thiagarajan, S., Semmel, D. S., \& Semmel, M. I. 1974. Instructional Development for Training Teachers of Excptional Children . Indiana: Center for innovation.

Trianto. 2007. Model Pembelajaran Terpadu dalam Teori dan Praktek. Jakarta: Prestasi Pustaka.

Trianto. (2013). Model Pembelajaran Terpadu. Jakarta: Bumi Aksara.

Tuckman, B.W. 1986. Conducting Educational Research Second Edition. USA: Harcourt Brace Jovanovich, Publisher.

Turpin, Tammye. 2004. The Effects of an Integrated, Activity-Based Science Curriculum on Student Achievement, Science Process Skills, and Science Attitudes. Electronic journal of literacy through science, Volume 3, pp 1-17.

Wardhana, W. A. 2004. Dampak Pencemaran Lingkungan. Yogyakarta: Andi.

Widoyoko, E. P. 2012. Teknik Penyusunan Instrumen Penelitian. Yogyakarta: Pustaka Pelajar.

$\mathrm{Wu}$, Weishen. 2007. The Development of an Instrument For a Technology-integrated Science Learning Environment. International Journal. pp 1-24. 